\title{
Legal and Regulatory News from Europe
} Julian Hitchcock*

\section{ABSTRACT}

An opinion presented to the Court of Justice of the European Union on the patentability of parthenotes challenges the court's own competence in a notorious case on human embryonic stem cells.

\section{Is Brüstle unraveling?}

On July 17, Advocate General Cruz Villalón of the Court of Justice of the European Union (CJEU) handed down his opinion in the case of International Stem Cell Corporation $v$ Comptroller of Patents. ${ }^{1}$ It's not a judgment, but an expert guide that the CJEU must take into account in reaching a final decision. ${ }^{2}$ The opinion is interesting because, in effect, the subject matter obliges the CJEU to revisit its notorious 2011 decision in Brüstle v Greenpeace.

If human embryonic stem cell (hESCthe stuff of Brüstle) patents appear rather niche, then International Stem Cell may look like a cranny. And, for those wishing to be spared all the implications and analysis of the case, I'll tell you the outcome: the advocate general doesn't think parthenotes should be classed as "human embryos"; he's advising the CJEU to rule that they should be patentable in the EU, but that member states are entitled to ban the patenting of parthenotes if they so wish. If the CJEU agrees, then you can expect the European Patent Office to agree, thereby spreading the principle

Lawford Davies Denoon, London, United Kingdom. *Correspondence: julian@lawforddaviesdenoon .com)

${ }^{1}$ Case C-364/13.

${ }^{2}$ Case C-24/10 (October 18, 2011).

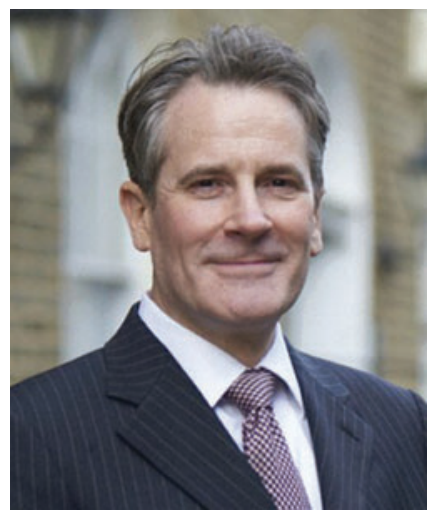

Julian Hitchcock is an attorney in London focusing on the life sciences, particularly the regulation of stem cells.

to non-EU countries such as Turkey, Norway, and Switzerland. But International Stem Cell Corporation is less about parthenotes than about the competence of the court that decides it.

\section{Context}

When the CJEU decided in Brüstle to ban the patenting of inventions derived from fertilized eggs or their equivalent, some scientists and patent attorneys pronounced disaster. Ironically, however, the decision made Europe a more attractive place to undertake embryonic stem cell research, not less. It affected the patentability of all inventions equally wherever they came from in the world: European researchers could get hESC patents outside Europe just like everyone else, and no one outside Europe could get an hESC patent in Europe either. In fact, as many scientists had claimed that hESC patents had been putting a brake on research, ${ }^{3}$ cutting the brake cable gave European researchers an advantage over U.S. counterparts: no chilling effect here. Add to this the fact that, where cells are used therapeutically, they enjoy an unlimited monopoly irrespective of patent protection, ${ }^{4}$ and the Brüstle decision appears as relevant to stem cell endeavor as a homily on the numbers of angels permitted to straddle needles.

Nevertheless, there are three significant reasons why the case mattered and still matters. First, investors misunderstood it: didn't the scientists themselves say it was a disaster? Second, those opposed to hESC research use it to argue against EU funding and for greater EU interference in biomedical legislation and medical practice. They failed on the funding: first in an attempt to derail "Horizon 2020" finance and then, in May, in an EU 'citizens' initiative." However, they did succeed in

\footnotetext{
${ }^{3}$ Hinxton Group "Consensus Statement," January 21, 2011. http://hinxtongroup.wordpress. com/2011/01/21/consensus_statement/ Given statutory defenses for experimental purposes relating to the subject matter of an invention, this belief may be questioned legally, but it is undoubtedly sincere.

${ }^{4}$ As a consequence of Directive 2001/83.
} 
persuading the European Parliament to add intrusive elements to a new regulation on in vitro diagnostic devices ${ }^{5}$ and will doubtless make further claims.

The third reason that the case matters is that the decision can only be followed as far as the World Trade Organization (WTO) Agreement allows under Trade Related Aspects of Intellectual Property rightS (TRIPS), the WTO's intellectual property rules. It's true that WTO members can exclude "inventions, the prevention within their territory of the commercial exploitation of which is necessary to protect ordre public or morality," 6 but as the EU and member states not only permit exploitation, but also actively encourage it, it certainly isn't necessary to exclude patentability. Without necessity, they are obliged to offer patent protection, subject to the usual rules on novelty, inventiveness, and so forth. ${ }^{7}$ Adherence to the judgment could therefore expose the EU and its members states to proceedings before the WTO.

\section{International Stem Cell}

The oddest thing about the new case is that it had to be brought at all. It had to be, first, because the UK Intellectual Property Office acquiesced in the Brüstle decision (apparently heedless of TRIPS), and, second, because even though the subject matter of International Stem Cell's (ISC's) patent application fell within the CJEU's definition of human embryo, it was plainly absurd. The reason is both telling and important.

In 2007, Elena Revazova and colleagues at ISC demonstrated the potential of parthenotes as a source of therapeutic stem cells [1] by coaxing an ovum to divide into something like a blastocyst, replete with pluripotent stem cells but no

${ }^{5}$ Beyond the EU's legal competence to legislate; see www.eshg.org/fileadmin/eshg/documents/IV D/ESHG_Opinion_19_February_2014_final.pdf

${ }^{6}$ Article 27(2) TRIPS.

${ }^{7}$ European Intellectual Law Review [EIPR] 2014, vol. 36, issue 6, p. 390 totipotent ones. ISC applied for two U.K. national patents. The first was entitled "Parthenogenetic activation of oocytes for the production of human embryonic stem cells." It claimed methods for producing pluripotent human stem cell lines from parthenogenetically activated oocytes, as well as stem cell lines produced by those methods. The second application was entitled "Synthetic cornea from retinal stem cells." It claimed methods of producing synthetic cornea or corneal tissue that involve the isolation of pluripotent stem cells from parthenogenetically activated oocytes as well as synthetic cornea or corneal tissue produced by these methods.

The use of "human embryos" for industrial or commercial purposes may not be patented under Article 6 of the EU Biotechnology Directive. If a parthenogenetically activated oocyte falls within the definition of "human embryo" in the directive, it will therefore be unpatentable. But the directive lacks a definition. The reason that the Brüstle case was referred to the CJEU was to get the court to supply one. And this is what it concluded:

“Article 6(2)(c) of Directive 98/44/EC ... must be interpreted as meaning that ... any human ovum after fertilisation, any non-fertilised human ovum into which the cell nucleus from a mature human cell has been transplanted, and any non-fertilised human ovum whose division and further development have been stimulated by parthenogenesis constitute a 'human embryo.","8

It reached this decision because it considered a "human embryo" to be an organism "capable of commencing the process of development of a human being." Whence this seminal definition? From technical information provided to the court under its Advocate General Yves Bot. As the CJEU explained, although CNR organisms and parthenotes "have not, strictly speaking, been the object of fertilisation, due to the effect of the

${ }^{8}$ Case C-24/10. technique used to obtain them they are, as apparent from the written observations presented to the Court, capable of commencing the process of development of a human being, just as an embryo created by fertilisation of an ovum can do so." ${ }^{9}$ On the basis of the same observations, it went on to suggest that parthenotes were a source of totipotent cells, which they are not.

The scientifically literate were shocked to discover this: for example, it had been known since the mid 1980s that a double complement of maternally imprinted genes and the absence of paternally imprinted genes render human development impossible. ${ }^{10}$ How could these written observations have missed something so fundamental?

Over and over again, the International Stem Cell opinion points to a failure of scientific understanding by the court: not only ISC, but also the governments of France, Sweden, and the UK, the European Commission, and the advocate general himself all complain about the quality of scientific information in Brüstle, the commission (ignoring Surani's imprinting experiments of 198487) diplomatically suggesting that the written submissions had "proved erroneous in the light of scientific developments." Advocate General Cruz Villalón is more pointed:

"Had the Court been aware of the fundamental difference between parthenotes and nonfertilised ova subjected to somatic-cell nuclear transfer and nevertheless wanted to establish a functional equivalence between the two, it would certainly have discussed this difference."

\section{What next?}

The CJEU will presumably follow the advocate general's advice and confirm that

\footnotetext{
${ }^{9}$ Para 36, Case C-24/10.

${ }^{10}$ Surani, Barton and Norris: Nature (1984), 308 (548-550) \& 311 (374-376); (1987) 326 (395-397). For a good lay introduction, see also pages 116 to 119 of The Epigenetics Revolution, Nessa Carey (Icon, 2011).
} 
human parthenotes should not be classed as human embryos and that, therefore, they are patent-eligible subject matter, with options for member states to ban patenting if necessary on moral grounds.

Between the lines, however, the advocate general may be asking for rather more. The very first words of his opinion are, "These proceedings offer the Court of Justice an opportunity to consider, again, the meaning of 'human embryos' in Article 6(2) of Directive 98/44." Is the CJEU being encouraged to consider the position rather more broadly? It certainly should. By exposing the Brüstle court's poor scientific understanding of critical subject matter, doubt is cast upon its overall competence. Oddly, Advocate General Bot's Brüstle opinion got off to a promising start. Here he is looking for clues for the missing human embryo definition:

"The provisions of Directive 98/44 provide an important indication. What should be defined? The appearance of life? The amazing moment when, in utero, what was perhaps only a group of cells changes in nature and becomes, whilst not yet a human being, an object, or even a subject of law? Not at all. This is not the question which follows from the wording and the approach taken by the directive which, through the wise wording it uses, leads us to define not life, but the human body. It is 'the human body, at the various stages of its formation and development'for which it demands protection when it declares it expressly unpatentable." 11

Advocate General Bot is quoting Article 5 of the Directive. Whereas Article 6 concerns uses of human embryos, the entities themselves are effectively defined in Article 5: bodies.

So far so good (legally). It enables the advocate general to focus on what should

${ }^{11}$ Para 72 have been the key question: when does the human body form? Plainly, this is a scientific question. Signally, however, AG Bot launched straight into the subject of ethics. Indeed, ethical considerations became the facts in the case. The realities of biology give way to a confusion of human bodies, persons, life, and dignity.

AG Bot may have been wrong, but if he reached his understanding on the basis of technical information provided to him, shouldn't we cut him some slack? Certainly, it was AG Bot's job to apprise the CJEU of the science required to consider his legal opinion. As the ISC case highlights, he failed; incorrect evidence was, apparently, accepted without challenge. Had the court been correctly apprised, it would have had to consider the question of bodily formation more thoroughly, just as it should have considered the parthenote question more thoroughly. Yet, the work of Edward Lewis, Christiane Nüsslein-Volhard, and Eric Wieschaus went unremarked despite their Nobel Prize for identifying the Hox genes that are essential to the formation of the human body, its head-to-tail axis, segmentation, and the specialization into different organs; the "primitive streak" doesn't appear once. It's particularly serious as it affects not merely an individual case, but the application of European law generally. Nevertheless, the flaw lies not in any individual advocate general, but in the system that allowed such an error to be perpetuated.

The International Stem Cell case has already exposed the unreliability of the Brüstle definition. The newly constituted CJEU will probably agree with Advocate General Cruz Villalón that the appropriate test of a human embryo is the "inherent capacity of developing into a human being." Although it is unlikely to address the validity of this

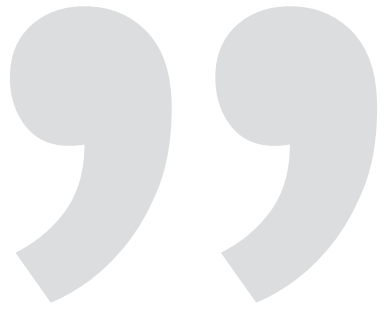

\section{The flaw lies not in any individual advocate general, but in the system that allowed such an error to be perpetuated.}

underlying "inherent capacity" principle, the court will be painfully aware that not only has the authority of its Brüstle decision been undermined, but also that its own competence has been cast into doubt.

\section{Author Disclosure} Statement

Neither the author nor Lawford Davies Denoon acts on behalf of any of the parties referred to in this article or expects to receive any commercial or personal benefit as a result of its publication.

\section{REFERENCE}

1. Revazova ES, NA Turovets, OD Kochetkova, LB Kindarova, LN Kuzmichev, JD Janus and MV Pryzhkova. (2007). Patient-specific stem cell lines derived from human parthenogenetic blastocysts. Cloning Stem Cells 9:432-449. 